\title{
Nonsyndromic Bilateral Posterior Maxillary Supernumerary Teeth: A Report of Two Cases and Review
}

\author{
Ravi Kumar Mahto (D, ${ }^{1}$ Shantanu Dixit, ${ }^{2}$ Dashrath Kafle, ${ }^{1}$ Aradhana Agarwal, ${ }^{1}$ \\ Michael Bornstein, ${ }^{3}$ and Sanad Dulal ${ }^{4}$ \\ ${ }^{1}$ Department of Orthodontics, Dhulikhel Hospital, Kathmandu University School of Medical Sciences, \\ Dhulikhel, Nepal \\ ${ }^{2}$ Department of Oral Medicine and Radiology, Dhulikhel Hospital, Kathmandu University School of Medical Sciences, \\ Dhulikhel, Nepal \\ ${ }^{3}$ Oral and Maxillofacial Radiology, Applied Oral Sciences, Faculty of Dentistry, University of Hong Kong, \\ Pokfulam, Hong Kong \\ ${ }^{4}$ Department of Oral and Maxillofacial Surgery, Dhulikhel Hospital, Kathmandu University School of Medical Sciences, \\ Dhulikhel, Nepal \\ Correspondence should be addressed to Ravi Kumar Mahto; drravimahto@gmail.com
}

Received 25 January 2018; Accepted 18 March 2018; Published 11 April 2018

Academic Editor: Gavriel Chaushu

Copyright (c) 2018 Ravi Kumar Mahto et al. This is an open access article distributed under the Creative Commons Attribution License, which permits unrestricted use, distribution, and reproduction in any medium, provided the original work is properly cited.

\begin{abstract}
Supernumerary tooth/hyperdontia is defined as those teeth which are present in excess of the usual distribution of twenty deciduous and thirty-two permanent teeth. It can be seen in both syndromic and nonsyndromic patients. In Nepalese population, prevalence of supernumerary tooth is documented to be $1.6 \%$. To the best of our knowledge, no studies from Nepal have reported the incidence of bilateral maxillary paramolars or the combination of unilateral maxillary paramolar and distomolar till date. Hence, we are reporting these two cases with a brief review of literature to put emphasis on incidence, prevalence, proposed hypothesis for etiology, and management of supernumerary teeth.
\end{abstract}

\section{Introduction}

Supernumerary tooth (ST) is defined as a tooth or a structure resembling tooth which forms from dental lamina in addition to the normal dental formula $[1,2]$. It can occur both in the maxillae and/or mandible, unilaterally or bilaterally, solitary or in multiples, and erupted or unerupted. It can be seen in both syndromic and nonsyndromic patients. Previous researches had documented the prevalence rate of ST to be $0.2 \%-0.8 \%$ and $0.5 \%-5.3 \%$ in deciduous and permanent dentition, respectively. The male-to-female ratio for the incidence of ST was reported to range in between 1.18:1 and $1.5: 1$. Supernumerary teeth are also associated with larger than average teeth which reflect their multifactorial etiology. Various hypothesis were postulated by different authors to explain the phenomena of ST development, but the exact etiology is still unknown [3]. However, Brook [4] had hypothesized an interaction of environmental and genetic factors.

ST can be classified on the basis of the morphology (conical, tuberculate, supplemental, and odontomes), location (mesiodens, paramolar, distomolar, and parapremolar), position (buccal, palatal, and transverse), and orientation (vertical or normal, inverted, transverse, or horizontal). Mesiodens is the most prevalent supernumerary teeth which is seen in premaxilla. ST in the molar region is comparatively very rare [3]. Also, a very few cases have been reported about the bilateral presence of ST in the molar region [5].

Hence, we are reporting two cases of bilateral ST in the molar region. Our first case is of bilateral maxillary paramolars, whereas the other case is a combination of unilateral maxillary paramolar and distomolar. In addition, we have 

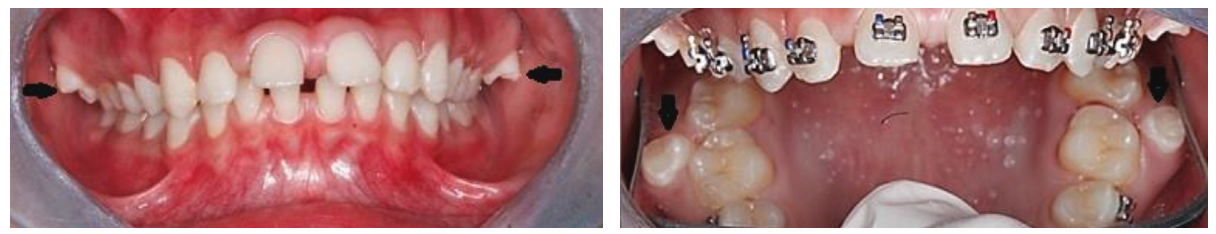

FIGURE 1: Intraoral images of Case 1 depicting bilateral maxillary paramolars (shown by arrows).
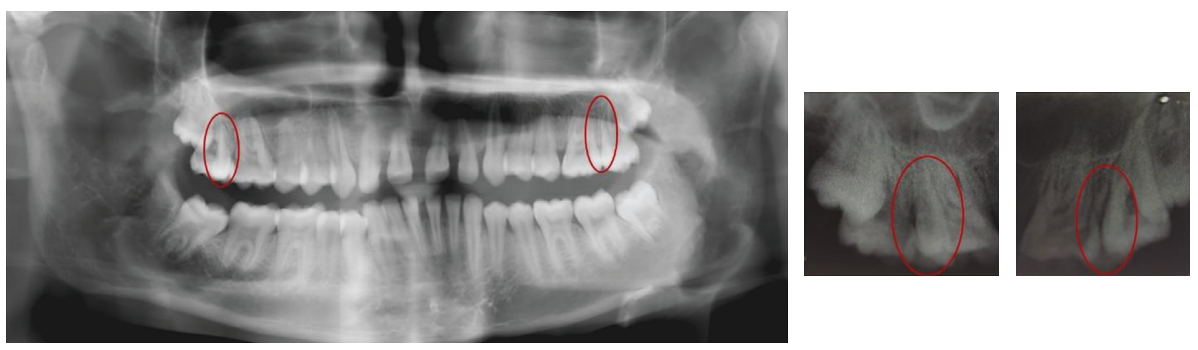

FiguRE 2: Panoramic and intraoral radiographs showing bilateral maxillary paramolars (encircled).

reviewed the existing literature to focus on incidence, prevalence, proposed hypothesis for etiology, and management of supernumerary teeth.

\section{Case Report 1}

A 17-year-old male patient visited to the department of orthodontics and dentofacial orthopedics with a chief complaint of malalignment of teeth. His medical and family histories were not significant. On intraoral examination, buccally placed bilateral paramolars were present in between first and second maxillary molars (Figure 1). No clinical complications were present secondary to paramolars. Radiological investigations (intraoral periapical radiographs and panoramic radiograph) were advised to determine the root orientation (Figure 2). Both the paramolars were vertically oriented. Extractions were advised for both the paramolars to prevent any interruption in the orthodontic treatment. Extracted paramolars showed supplemental shape and form with well-defined transverse and marginal ridges resembling maxillary premolars (Figure 3). It was followed by initiation of the orthodontic treatment.

\section{Case Report 2}

A 23-year-old female patient visited to the department of orthodontics and dentofacial orthopedics with a chief complaint of forwardly placed upper front teeth. No significant medical and family histories were reported. On intraoral examination, fourteen teeth were present in maxillary arch (Figure 4). Clinically, maxillary third molars were missing bilaterally. She was advised for routine radiological investigations required for the orthodontic treatment. Panoramic radiograph revealed presence of a distomolar on the right side and a paramolar between left second and third molars (Figure 5). Computed tomographic scan was advised to know the accurate orientation of these impacted supernumerary teeth to formulate the treatment

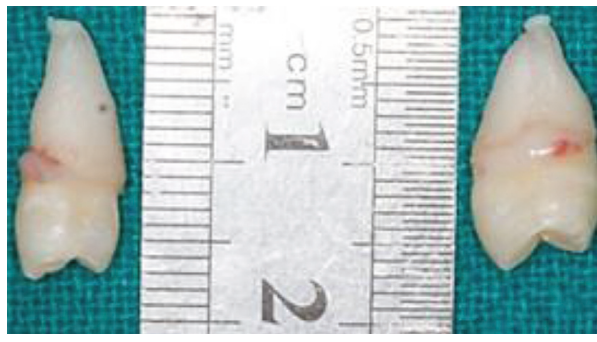

FIGURE 3: Extracted paramolars resembling maxillary premolars.

plan. It revealed the vertical orientation of both the impacted supernumerary teeth. Extraction of supernumerary teeth followed by the orthodontic treatment was advised to the patient.

\section{Discussion}

ST or hyperdontia as defined earlier are those teeth which are present in excess of the usual distribution of twenty deciduous and thirty-two permanent teeth [6]. Singh et al. had reported the prevalence of ST in Nepalese population to be $1.6 \%$, which was in accordance with Hungarian (1.53\%), Swedish (1.6\%), and Brazilian (1.7\%) population. The same study had showed the male predilection for ST with male: female ratio of $1.3: 1$ which was similar to Hungarian (1.4:1), British (1.4:1), and Brazilian (1.45:1) population [7-11]. Similarly, this study had also documented the prevalence of the single ST to be the most commonest (82.60\%) followed by paired (15.21\%) and triple ones (2.17\%). Maxillary arch (98.8\%) with the anterior medial region (mesiodens) and conical form was found to be the most common location and form of the supernumerary teeth in this study [7].

To the best of our knowledge, no studies from Nepal have reported the incidence of bilateral maxillary paramolars or the combination of unilateral maxillary paramolar and distomolar till date. The documented incidences similar to 

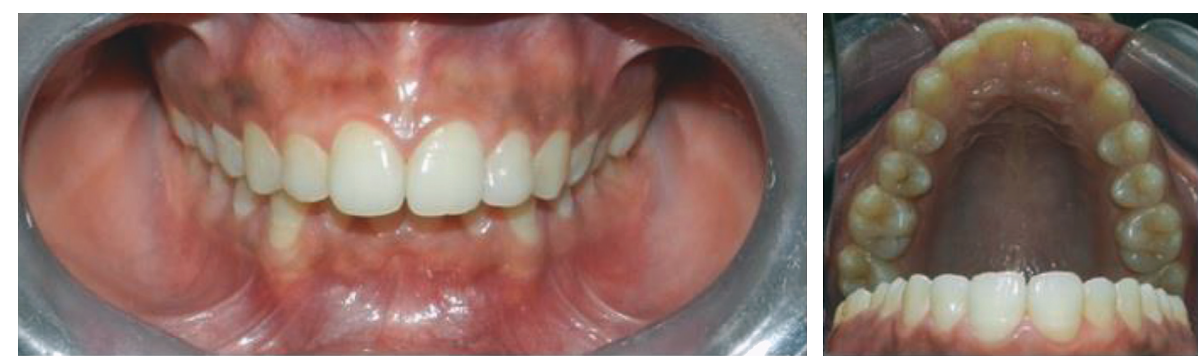

Figure 4: Intraoral images of Case 2.

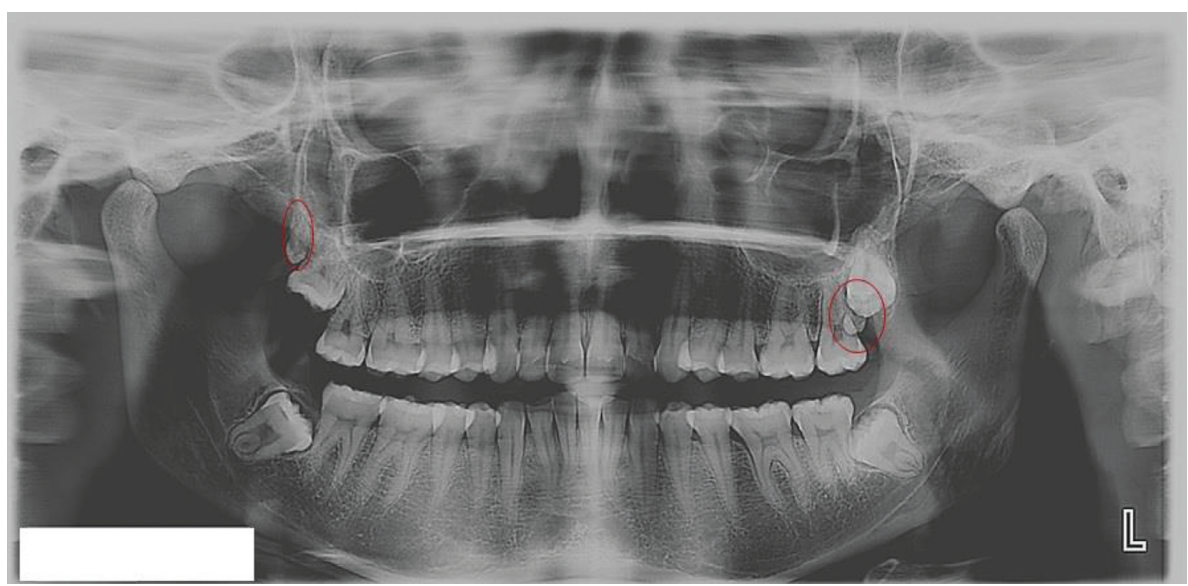

FIGURE 5: Panoramic radiograph showing maxillary the right distomolar and left paramolar (encircled).

our cases reported in other population are briefed in Tables 1 and 2 [12, 13]. Hou et al. [14], Dhull et al. [15], Shetty [16], and Sulabha and Sameer [17] had reported the presence of bilateral maxillary paramolars similar to our first case report. Nirmala and Tirupathi [12] had documented the combination of unilateral maxillary paramolar and distomolar similar to our second case report.

The exact etiology of occurrence of ST is not known. Numerous theories have been postulated to understand their existence along with the normal dentition. Atavism theory stated the occurrence of supernumerary teeth as the phylogenetic reversion to the extinct ancestral human dentition [33]. Dichotomy theory suggested that a developing tooth bud can divide into two teeth, giving rise to ST and a normal tooth [34]. Dental lamina hyperactivity theory, the most accepted one, suggests the localized and independent hyperactivity of the dental lamina to be the cause for the development of ST [7, 35]. Niswander and Sujaku [36] also proposed the presence of an autosomal recessive gene which explains the familial tendency to ST. It have been reported in patients with syndromes like cleft lip and palate, cleidocranial dysplasia, Ehlers-Danlos syndrome type III, Fabry-Anderson's syndrome, Ellis-van Creveld syndrome, Gardner's syndrome, Goldenhar syndrome, HallermannStreiff syndrome, orofaciodigital syndrome type I, incontinentia pigmenti, Marfan syndrome, Nance-Horan syndrome, and trichorhinophalangeal syndrome 1 [12].

ST may be associated with different clinical complications. These can result into clinical problems like midline diastema; crowding; malocclusion due to insufficient space; dilaceration, delayed, or failure of eruption of permanent teeth; root resorption of adjacent teeth; cyst formation; cheek bite; periodontal problems; dental caries, and other difficulties related to ectopic position. These complications occur rarely, but earlier diagnosis can help to prevent these complications $[4,13]$.

Radiographic screening plays a significant role in identification and localization of ST, especially when they are impacted or need surgical intervention. Twodimensional imaging modalities (periapical radiographs, occlusal radiographs, and orthopantomographs) do provide sufficient information to the clinicians, but accurate position of buccally or lingually placed ST is difficult to determine due to the superimposition by the surrounding structures [4, 13, 37]. Clark and Richards had suggested horizontal and vertical tube shift technique, respectively, to determine exact location of ST using conventional radiography. Both of these are widely accepted due to their simplicity [4, 38, 39]. Recently, Toureno et al. proposed a guideline to use three-dimensional imaging modalities (cone beam computerized tomography) along with twodimensional imaging modalities for better assessment of ST, planning surgical intervention with minimal treatment errors [40].

There are two different school of thoughts about the management of ST. Some authors recommended the removal of ST as soon as detected, whereas others emphasized the periodic monitoring and removal only in the case of any 
TABLE 1: Reported cases of paramolars.

\begin{tabular}{|c|c|c|c|c|c|c|c|c|}
\hline \multirow{2}{*}{ Arch/side } & \multicolumn{4}{|c|}{ Unilateral } & \multicolumn{4}{|c|}{ Bilateral } \\
\hline & Author & Year & Population & Location & Author & Year & Population & Location \\
\hline \multirow{4}{*}{ Maxillae } & $\begin{array}{l}\text { Puri et al. } \\
\quad[18]\end{array}$ & 2013 & Indian & $\begin{array}{l}\text { Bucally placed between } \\
\text { second and third molars }\end{array}$ & $\begin{array}{c}\text { Sulabha and } \\
\text { Sameer et al. } \\
\text { [17] }\end{array}$ & 2015 & Indian & $\begin{array}{l}\text { Buccally placed between } \\
\text { first and second molars }\end{array}$ \\
\hline & $\begin{array}{c}\text { Nayak et al. } \\
{[19]}\end{array}$ & 2012 & Indian & $\begin{array}{l}\text { Palatally placed between left } \\
\text { first and second molars }\end{array}$ & Dhull et al. [15] & 2012 & Indian & $\begin{array}{l}\text { Between first and second } \\
\text { molars }\end{array}$ \\
\hline & $\begin{array}{l}\text { Nagaveni } \\
\text { et al. [13] }\end{array}$ & 2010 & Indian & $\begin{array}{l}\text { Buccally placed between } \\
\text { right first and second molars }\end{array}$ & Shetty et al. [16] & 2012 & Indian & $\begin{array}{l}\text { Palatally placed between } \\
\text { first and second molars }\end{array}$ \\
\hline & & & & & Hou et al. [14] & 1995 & Taiwanese & $\begin{array}{l}\text { Buccally placed between } \\
\text { first and second molars }\end{array}$ \\
\hline \multirow{9}{*}{ Mandible } & $\begin{array}{l}\text { Ghogre and } \\
\text { Gurav [20] }\end{array}$ & 2014 & Indian & Fused with the second molar & Dhull et al. [15] & 2014 & Indian & $\begin{array}{l}\text { Mesial and lingual to the } \\
\text { second molar }\end{array}$ \\
\hline & $\begin{array}{l}\text { Venugopal } \\
\text { et al. [21] }\end{array}$ & 2013 & Indian & $\begin{array}{l}\text { Fused with the right second } \\
\text { molar }\end{array}$ & $\begin{array}{l}\text { Nunes et al. } \\
\text { [22] }\end{array}$ & 2002 & Brazil & $\begin{array}{l}\text { Fused with the second } \\
\text { molar }\end{array}$ \\
\hline & $\begin{array}{l}\text { Rudagi et al. } \\
\text { [23] }\end{array}$ & 2012 & Indian & $\begin{array}{l}\text { Fused with the left second } \\
\text { molar }\end{array}$ & & & & \\
\hline & $\begin{array}{l}\text { Salem et al. } \\
\text { [24] }\end{array}$ & 2010 & Iran & $\begin{array}{l}\text { Fused with the left second } \\
\text { molar }\end{array}$ & & & & \\
\hline & $\begin{array}{l}\text { Rosa et al. } \\
\quad[25]\end{array}$ & 2010 & Brazil & $\begin{array}{l}\text { Fused with the right first } \\
\text { molar }\end{array}$ & & & & \\
\hline & $\begin{array}{l}\text { Ballal et al. } \\
\text { [26] }\end{array}$ & 2007 & Indian & Fused with the second molar & & & & \\
\hline & $\begin{array}{l}\text { Ghoddusi } \\
\text { et al. [27] }\end{array}$ & 2006 & Iran & $\begin{array}{l}\text { Fused with the left second } \\
\text { molar }\end{array}$ & & & & \\
\hline & $\begin{array}{l}\text { Dubuk et al. } \\
\text { [28] }\end{array}$ & 1996 & Japanese & $\begin{array}{l}\text { Mesial to the right second } \\
\text { molar }\end{array}$ & & & & \\
\hline & $\begin{array}{l}\text { Kumasaka } \\
\text { et al. [29] }\end{array}$ & 1988 & Japanese & $\begin{array}{l}\text { Two impacted paramolar on } \\
\text { the right side }\end{array}$ & & & & \\
\hline
\end{tabular}

TABLE 2: Reported cases of combination of paramolar and distomolar/bilateral paramolars.

\begin{tabular}{|c|c|c|c|c|}
\hline Arch & Author & Year & Population & Location \\
\hline \multirow{4}{*}{ Maxillae } & Present case & 2017 & Nepalese & $\begin{array}{c}\text { Buccally placed bilateral paramolars in between first } \\
\text { and second molars; combination of a distomolar on } \\
\text { the right side and a paramolar between left second } \\
\text { and third molars }\end{array}$ \\
\hline & Nirmala and Tirupathi [12] & 2015 & Indian & $\begin{array}{l}\text { Combination of developing unerupted paramolar on } \\
\text { the right side and distomolar on the left side }\end{array}$ \\
\hline & Omal et al. [30] & 2011 & Indian & $\begin{array}{c}\text { Bilateral paramolar between second and third molars; } \\
\text { bilaterally impacted distomolar }\end{array}$ \\
\hline & Mayfield and Casamassimo [31] & 1990 & Hispanic & Bilateral paramolars and distomolars \\
\hline Mandible & Reddy et al. [32] & 2013 & Indian & $\begin{array}{l}\text { Bilateral paramolar between first and second molars; } \\
\text { bilateral distomolar with impacted second molar }\end{array}$ \\
\hline
\end{tabular}

associated pathology or hindrance to any dental treatment especially the orthodontic treatment [41-43]. Hogstrom and Andersson also suggested two different options for ST removal. According to them, ST either should be removed as early as it is identified or after completion of the adjacent tooth's root formation. However, former option could result into creation of dental phobia in young children and can disturb the growth of adjacent teeth [44]. Recently, Omer et al. suggested the optimal time for the removal of ST during 6 to 7 years, based upon their retrospective analysis. According to them, during this age interval, ST removal can be done with minimal disturbances to the adjacent teeth [1].

\section{Conclusion}

Supernumerary teeth are uncommon and generally present without causing any complications like our cases. Our cases required surgical intervention for future orthodontic treatment and planning. Although complications are rare, clinicians should be aware of early identification, proper management, and associated complications with the same.

\section{Conflicts of Interest}

The authors declare that there are no conflicts of interest regarding the publication of this article. 


\section{References}

[1] R. S. Omer, R. P. Anthonappa, and N. M. King, "Determination of the optimum time for surgical removal of unerupted anterior supernumerary teeth," Pediatric Dentistry, vol. 32, no. 1, pp. 14-20, 2010.

[2] M. T. Cobourne and P. T. Sharpe, "Making up the numbers: the molecular control of mammalian dental formula," Seminars in Cell \& Developmental Biology, vol. 21, no. 3, pp. 314-324, 2010.

[3] X.-P. Wang and J. Fan, "Molecular genetics of supernumerary tooth formation," Genesis, vol. 49, no. 4, pp. 261-277, 2010.

[4] A. H. Brook, "A unifying aetiological explanation for anomalies of human tooth number and size," Archives of Oral Biology, vol. 29, no. 5, pp. 373-378, 1984.

[5] S. K. Mallineni, "Supernumerary teeth: review of the literature with recent updates," Conference Papers in Science, vol. 2014, Article ID 764050, 6 pages, 2014.

[6] C. Schulze, "Developmental abnormalities of the teeth and jaws," in Toma's Oral Pathology, R. J. Gorlin and H. M. Goldman, Eds., pp. 112-122, C.V. Mosby, St. Louis, MI, USA, 1970.

[7] V. P. Singh, A. Sharma, and S. Sharma, "Supernumerary teeth in Nepalese children," Scientific World Journal, vol. 2014, Article ID 215396, 5 pages, 2014.

[8] K. Gabris, G. Fabian, M. Kaan, N. Rozsa, and I. Tarjan, "Prevalence of hypodontia and hyperdontia in paedodontic and orthodontic patients in Budapest," Community Dental Health, vol. 23, no. 2, pp. 80-82, 2006.

[9] I. Bodin, P. Julin, and M. Tomsson, "Hyperdontia. I. Frequency and distribution of supernumerary teeth among 21,609 patients," Dentomaxillofacial Radiology, vol. 7, no. 1, pp. 15-17, 1978.

[10] F. X. P. C. Simoes, I. Crusoe-Rebello, F. S. Neves, C. Oliveira Santos, A. L. Ciamponi, and O. G. da Silva Filho, "Prevalence of supernumerary teeth in orthodontic patients from South Western Brazil," International Journal of Odontostomatology, vol. 5, no. 2, pp. 199-202, 2011.

[11] A. H. Brook, "Dental anomalies of number, form and size: their prevalence in British school children," Journal of the International Association of Dentistry for Children, vol. 5, no. 2, pp. 37-53, 1974.

[12] S. V. S. G. Nirmala and S. P. Tirupathi, "Rare combination of developing unerupted paramolar and distomolar in maxilla: a case report and review of literature," Journal of Interdisciplinary Medicine and Dental Science, vol. 4, no. 4, pp. 1-6, 2016.

[13] N. B. Nagaveni, K. V. Umashankara, N. B. Radhika, B. Praveen Reddy, and S. Manjunath, "Maxillary paramolar: report of a case and literature review," Archives of Orofacial Sciences, vol. 5, no. 1, pp. 24-28, 2010.

[14] G. L. Hou, C. C. Lin, and C. C. Tsai, "Ectopic supernumerary teeth as a predisposing cause in localized periodontitis. Case report," Australian Dental Journal, vol. 40, no. 4, pp. 226-228, 1995.

[15] K. S. Dhull, S. Acharya, P. Ray, S. Yadav, and S. D. Prabhakaran, "Bilateral maxillary paramolars: a case report," Journal of Dentistry for Children, vol. 79, no. 2, pp. 84-87, 2012.

[16] Y. N. Shetty, "A rare case of bilateral maxillary paramolars between 1st and 2nd molars," Journal of Orofacial Research, vol. 2, no. 1, pp. 52-55, 2012.

[17] A. N. Sulabha and C. Sameer, "Unusual bilateral paramolars associated with clinical complications," Case Reports in Dentistry, vol. 2015, Article ID 851765, 4 pages, 2015.
[18] K. Puri, M. Bansal, D. Jain et al., "Nonsyndromic multiple supernumerary premolars and paramolars: an overview and report of 2 cases," Indian Journal of Dental Sciences, vol. 5, pp. 54-56, 2013.

[19] G. Nayak, S. Shetty, I. Singh, and D. Pitalia, "Paramolar - A supernumerary molar: a case report and an overview," Dental Research Journal, vol. 9, pp. 797-803, 2012.

[20] P. Ghogre and S. Gurav, "Non-invasive endodontic management of fused mandibular second molar and a paramolar, using cone beam computed tomography as an adjunctive diagnostic aid: a case report," Journal of Conservative Dentistry, vol. 17, pp. 483-486, 2014.

[21] S. Venugopal, B. V. Smitha, and S. P. Saurabh, "Paramolar concrescence and periodontitis," Journal of Indian Society of Periodontology, vol. 17, pp. 383-386, 2013.

[22] E. Nunes, I. G. de Moraes, P. M. de Novaes, and S. M. de Sousa, "Bilateral fusion of mandibular second molars with supernumerary teeth: case report," Brazilian Dental Journal, vol. 13, pp. 137-141, 2002.

[23] K. Rudagi, B. M. Rudagi, S. Metgud, and R. Wagle, "Endodontic management of mandibular second molar fused to a supernumerary tooth, using spiral computed tomography as a diagnostic aid: a case report," Case Reports in Dentistry, vol. 2012, p. 614129, 2012.

[24] A. S. Milani, "Endodontic management of a fused mandibular second molar and paramolar: a case report," Iranian Endodontic Journal, vol. 5, pp. 131-134, 2010.

[25] F. M. Rosa, A. Stankiewicz, and I. M. Faraco, "Impaction of mandibular molar by supernumerary tooth: case report," Journal of Dentistry for Children, vol. 75, pp. 181-184, 2008.

[26] S. Ballal, G. S. Sachdeva, and D. Kandaswamy, "Endodontic management of a fused mandibular second molar and paramolar with the aid of spiral computed tomography: a case report," Journal of Endodontics, vol. 33, pp. 1247-1251, 2007.

[27] J. Ghoddusi, M. Zarei, and H. Jafarzadeh, "Endodontic treatment of a supernumerary tooth fused to a mandibular second molar: a case report," Journal of Oral Science, vol. 48, pp. 39-41, 2002.

[28] A. N. Dubuk, K. A. Selvig, G. Tellefsen, and U. M. Wikesjo, "Atypically located paramolar. Report of a rare case," European Journal of Oral Sciences, vol. 104, pp. 138-140, 1996.

[29] S. Kumasaka, K. Hideshima, H. Shinji et al., "A case of two impacted paramolar in lower right molar dentition," Kanagawa Shigaku, vol. 23, pp. 417-423, 1988.

[30] P. Omal, V. Jacob, J. Lonapan, and A. Kurian, "Bilateral fourth molars with paramolars in maxilla," Kerala Dental Journal, vol. 34, pp. 277-279, 2011.

[31] A. Mayfeld and P. S. Casamassimo, "Bilateral paramolars and fourth molars," Oral Surgery, Oral Medicine, Oral Pathology, Oral Radiology, vol. 69, p. 394, 1990.

[32] G. S. Reddy, G. V. Reddy, I. V. Krishna, and S. K. Regonda, "Nonsyndromic bilateral multiple impacted supernumerary mandibular third molars: a rare and unusual case report," Case Reports in Dentistry, vol. 2013, p. 857147, 2013.

[33] R. P. Anthonappa, N. M. King, and A. B. Rabie, "Aetiology of supernumerary teeth: a literature review," European Archives of Paediatrc Dentistry, vol. 14, pp. 279-288, 2013.

[34] W. Bateson, "On numerical variation in teeth, with a discussion of conception of homology," Proceedings of Zoological Society of London, vol. 102, no. 4, p. 115, 1982.

[35] G. V. Black, "Supernumerary teeth," Dental Summary, vol. 29, pp. 83-110, 1909. 
[36] J. D. Niswander and C. Sujaku, "Congenital anomalies of teeth in Japanese children," American Journal of Physical Anthropology, vol. 21, no. 4, pp. 569-574, 1963.

[37] M. Dojs and A. Roicka, "The usefulness of pantomographic $\mathrm{x}$-ray pictures in estimating the position of the paramolar and distomolar teeth," Annales Academiae Medicae Stetinensis, vol. 53, no. 1, pp. 83-85, 2007.

[38] C. A. Clark, "A method of ascertaining the relative position of unerupted teeth by means of film radiographs," Proceedings of Royal Society of Medicine, vol. 3, pp. 87-90, 1910.

[39] A. G. Richards, "Roentgenographic localization of the mandibular canal," Journal of Oral Surgery, vol. 10, pp. 325-329, 1952.

[40] L. Toureno, J. H. Park, R. A. Cederberg, E. H. Hwang, and J. W. Shin, "Identification of supernumerary teeth in 2D and 3D: review of literature and a proposal," Journal of Dental Education, vol. 77, no. 1, pp. 43-50, 2013.

[41] S. Rotberg and H. M. Kopel, "Early vs late removal of mesiodens: a clinical study of 375 children," Compendium of Continuing Education in Dentistry, vol. 5, pp. 115-119, 1984.

[42] D. Munns, "A case of partial anodontia and supernumerary tooth present in the same jaw," Dental Practitioner and Dental Record, vol. 18, no. 1, pp. 34-37, 1967.

[43] P. J. Scanlan and S. J. Hodges, "Supernumerary premolar teeth in siblings," British Journal of Orthodontics, vol. 24, no. 4, pp. 297-300, 1997.

[44] A. Hogstrom and L. Andersson, "Complications related to surgical removal of anterior supernumerary teeth in children," Journal of Dentistry for Children, vol. 54, no. 5, pp. 341-343, 1987. 


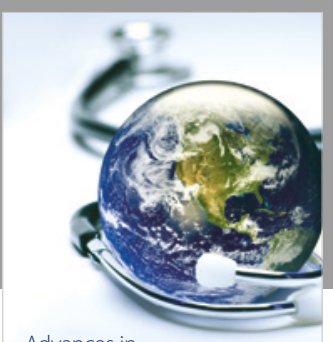

Advances in
Public Health

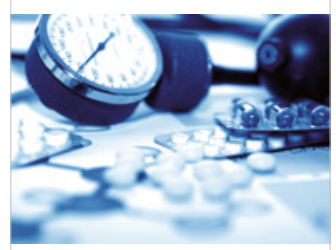

Case Reports in

Medicine

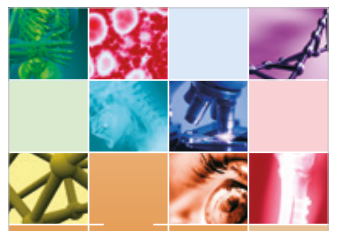

niernational Journal of

Biomaterials
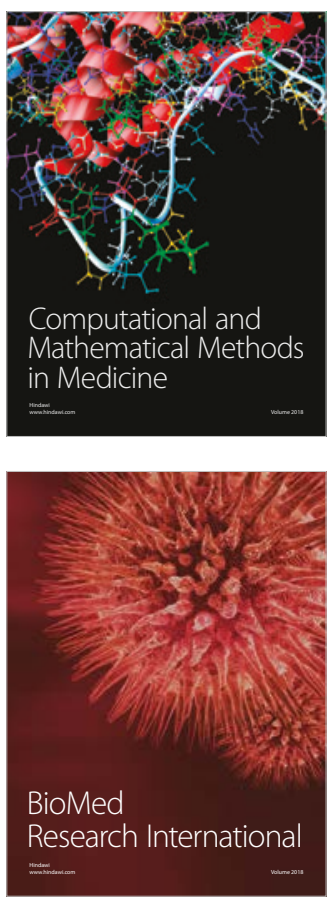

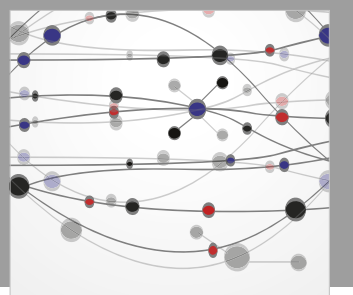

The Scientific World Journal Dentistry

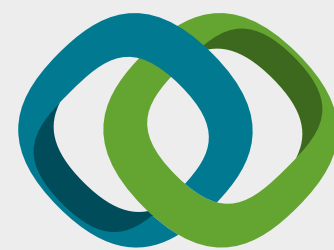

Hindawi

Submit your manuscripts at

www.hindawi.com
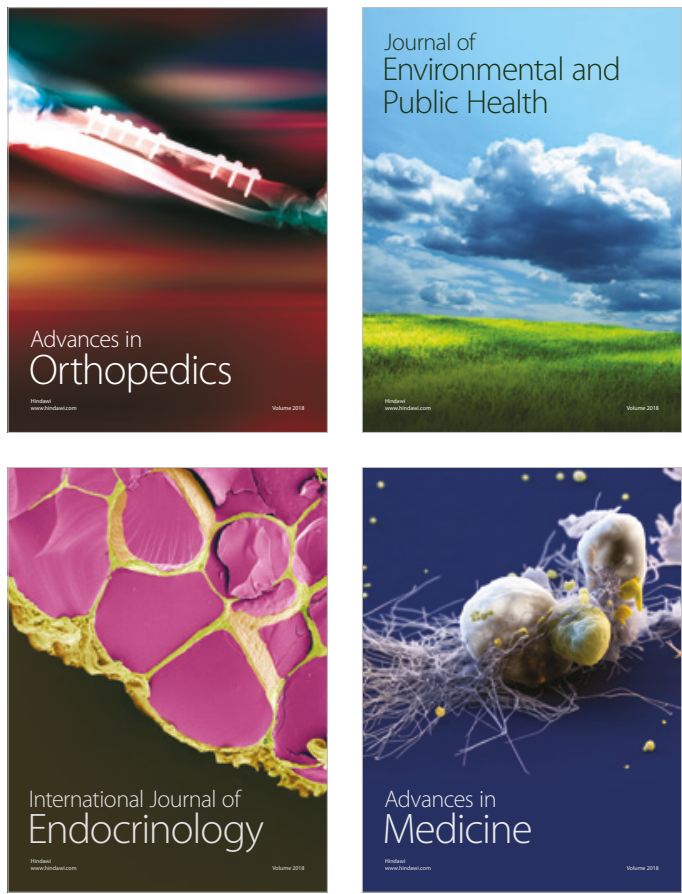
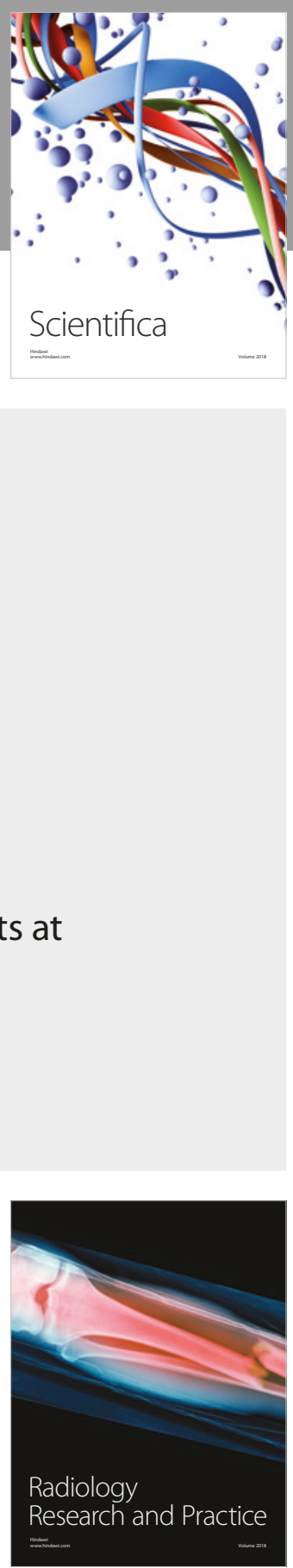

Scientifica

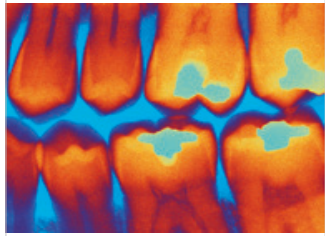

Case Reports in

Dentistry
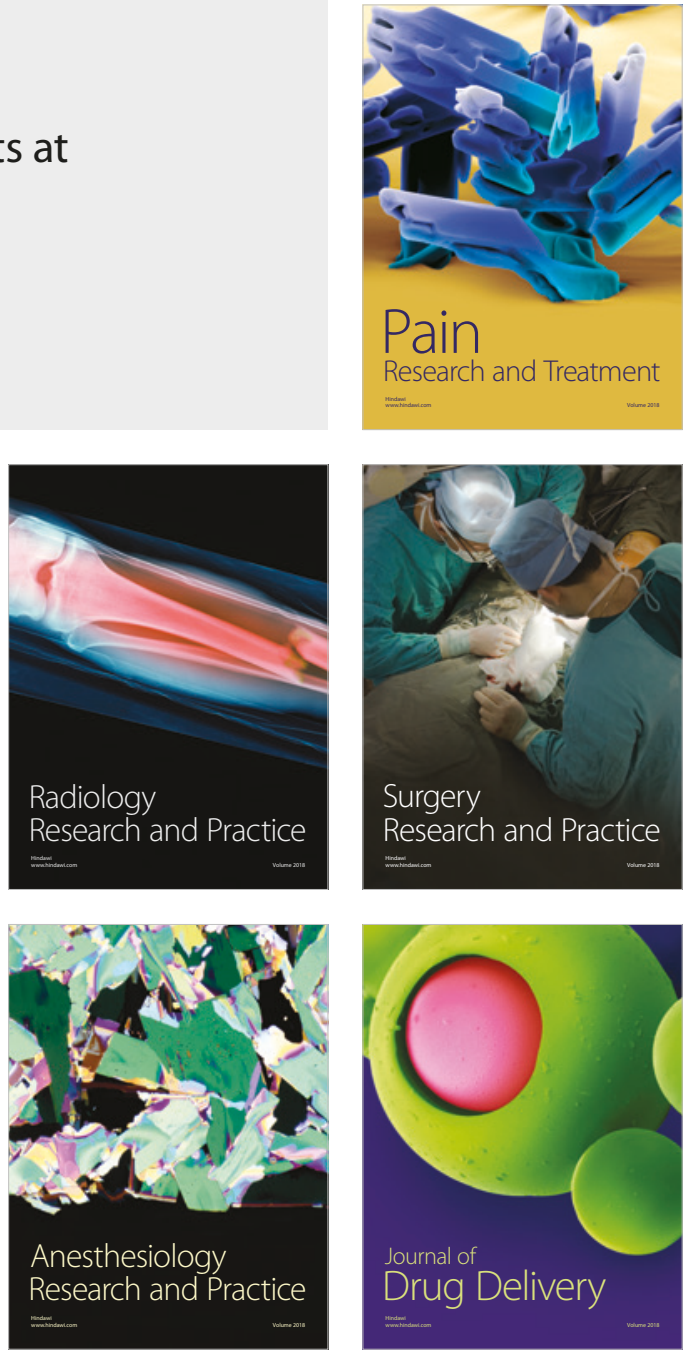